OPEN ACCESS

Edited by: Ivana Maguire, University of Zagreb, Croatia

Reviewed by: Elena Tricarico,

University of Florence, Italy

Christoph Chucholl,

Fischereiforschungsstelle Baden-Württemberg, Germany

${ }^{*}$ Correspondence: Armin Zenker armin.zenker@fhnw.ch

Specialty section: This article was submitted to Conservation and Restoration

Ecology,

a section of the journa

Frontiers in Environmental Science

Received: 22 September 2020 Accepted: 17 November 2020 Published: 09 December 2020

Citation:

Krieg R, King A and Zenker A (2020)

Measures to Control Invasive Crayfish

Species in Switzerland: A Success

Story? Front. Environ. Sci. 8:609129.

doi: 10.3389/fenvs.2020.609129

\section{Measures to Control Invasive Crayfish Species in Switzerland: A Success Story?}

\author{
Raphael Krieg, Alex King and Armin Zenker* \\ School of Life Sciences, Institute for Ecopreneurship, University of Applied Sciences and Arts Northwestern Switzerland, \\ Muttenz, Switzerland
}

Invasive crayfish species were first documented in Switzerland in the 1970s. Today, North American crayfish species dominate in most major lakes and streams in Switzerland. In combination with the crayfish plague, they pose a substantial threat to our native crayfish. Over the past 20 years, various techniques have been applied to reduce negative impacts of these invasive crayfish in Switzerland: eradication (temporary drainage or destruction of a water system, biocides), suppression (intensive trapping, electricity introduction of predatory fish) and containment (construction of crayfish barriers). Temporary drainage or filling-in of isolated ponds, in combination with calcium hydroxide application has been successful in eradicating populations of invasive crayfish. However, trapping and introduction of predatory fish led to a reduction in population density but neither method has ever caused the extinction of a population. Invasive crayfish have not yet reached crayfish barriers, therefore, long-term functionality of these barriers still needs to be proven. Nevertheless, functional controls with native crayfish have shown that barriers prevent their upstream movement. Implementation of crayfish barriers is the most promising method to protect native crayfish from displacement by invasive crayfish species. Many measures are expensive, time consuming, and show little or no success in controlling invasive crayfish. Therefore, we recommend to focus on implementing drastic measures, such as filling-in or draining of isolated waters or a combination of various methods to maximise the reduction of population size.

Keywords: biocides, trapping, barriers, infilling, electric-fishing, drainage, function control, migration

\section{INTRODUCTION}

Preventing the widespread disappearance of indigenous crayfish species (ICS) in Europe is an on-going challenge. In addition to habitat destruction by river engineering and water pollution, invasive non-indigenous crayfish species (NICS) from North America are becoming increasingly widespread in Europe and pose a major threat to ICS (Kouba et al., 2014). Their dominance over native species is reflected in their rapid reproduction (Burič et al., 2011), physical superiority and aggressiveness (Gherardi, 2006) as well as their tolerance to poor water quality (Nyström, 2002). Displacement of ICS with NICS is predicted whenever they occupy the same habitat niche (Westman et al., 2002); this is if the crayfish plague (Aphanomyces astaci) has not already initiated extinction of the native species. This fungus like pathogen belonging to the Oomycetes (Saprolegniales) was responsible for the first mass mortalities of native crayfish in Europe in the 
late ninetieth century and it continues to cause huge problems in waterways today (Holdich et al., 2009).

Various methods have already been applied and tested across the world to reduce or eradicate the negative impacts of the unwanted intruders as well as to prevent them from spreading further. These methods include: intensive trapping (Bills and Marking, 1988; Hein et al., 2007), male sterilisation (Piazza et al., 2015), the use of biocides (Cecchinelli et al., 2012), habitat destruction, the release of predators (Musseau et al., 2015), the construction of barriers (Cowart et al., 2018) or a multi-method approach combining different combinations of these methods (Hein et al., 2006; Freeman et al., 2010; Stebbing et al., 2014). The success of these measures varies and so far only attempts which fill-in isolated still waters or the use poison (Ballantyne et al., 2019) have been successful in completely eradicating populations of NICS.

In Switzerland, the three native species Astacus astacus (Linnaeus, 1758), Austropotamobius pallipes (Lereboullet, 1858) and Austropotamobius torrentium (von Paula Schrank, 1803) are threatened by the presence of three North American crayfish species. Faxonius limosus (Rafinesque, 1817) was detected for the first time in Switzerland in 1976. It was followed by Pacifastacus leniusculus (Dana, 1852) at the end of the 1980s and Procambarus clarkii (Girard, 1852) in the 1990s. F. limosus and $P$. leniusculus have spread rapidly across Switzerland and are, through transmission of the crayfish plague, the main reason for population extinction of ICS (Stucki and Zaugg, 2011).

The three native species in Switzerland are defined as internationally protected in Appendix III of the Convention on the Conservation of European Wildlife and Natural Habitats which was decided upon in the Bern Convention 1979. In order to protect these species, Switzerland is tackling not only reintroduction, conservation and habitat management but also containment, suppression and eradication of NICS (Hefti and Stucki, 2006).

This paper summarises and assesses the success of various measures taken so far to combat and prevent the spread of NICS in Switzerland. The results serve as a basis for the future strategy to manage invasive crayfish species in Switzerland and help other countries to implement similar measures.

\section{MATERIALS AND METHODS}

Cantonal fisheries departments in Switzerland provided information regarding which measures they had already taken and provided existing data about implementation and success of the methods. The data received was examined to assess whether it could be used to indicate the success of a control measure. When catch per unit effort (CPUE) values were recorded over several years or when the functionality of a crayfish barrier was tested in the field (function control) with ICS, data was assessed as "valid." Personal assessments, measures which have started within the last 3 years and catch figures without indication of the sampling effort were rated as "insufficient" to produce valid data and are classified and referred to as "unclear" success in this paper. "Success" was defined by the data which showed a reduction in CPUE by at least $75 \%$; when no invasive crayfish were detected above a crayfish barrier as well as when there was no further evidence of a crayfish appearance after an eradication campaign over a 5 year period. If CPUE decreased only by $\leq$ $25 \%$ after the eradication measurements were enforced this was judged as "no success."

\section{RESULTS}

Overall, nine cantons provided data regarding 40 control measures carried out at a total of 27 sites, 9 lotic and 18 lentic waterbodies (Table 1). Data on catch effort in large watersystems, such as Lake Zurich, Geneva and Neuchâtel as well as in the river Rhine, were insufficient and not included. When excluding sites which were classified as "unclear", $~ 83 \%$ of eradication, $20 \%$ of suppression, and $100 \%$ of containment methods were successful (Figure 1).

\section{Eradication of NICS}

Temporary drainage or destruction of habitat and the use of biocides are methods used to eradicate unwanted crayfish species in Switzerland. Attempts to eradicate populations of crayfish were successful at five out of seven sites including one isolated lotic waterbody. In one case success could not be evaluated because of insufficient data and the other attempt was unsuccessful.

\section{Temporary Drainage or Destruction of Habitat}

A 300-m section of the small brook, Stadtbach, Baden, which is isolated by culverts, contained a population of $P$. leniusculus. The stream section was completely drained in January and February 2004 and 2005. Crayfish were removed by hand following drainage but even after this crayfish could still be found. For the entire summer of 2013 this section of stream was left drained again and since then no crayfish have been detected (Stucki, 2018).

In 2013, complete drainage and hand removal of crayfish at two small quarry ponds, (Steinbruch Mellikon) led to the successful eradication of a population of $P$. clarkii. The project was carried out in close cooperation with the amphibian managers at this site (Stucki, 2018).

There was an attempt to eradicate $P$. clarkii inhabiting an artificial pond in a public park (l'étang de Vidy) by draining away all of the water and treating the soil with calcium hydroxide. After treatment, the soil at the bottom of the pond was removed. One year after the procedure, crayfish were still caught in traps in the pond. The process was repeated again, but this time refuges in the banks were also concreted over (Girardet et al., 2012). No crayfish have been detected since completing the second procedure.

Similar success was also achieved with another pond (Kunzareal, Rheinfelden) inhabited by P. clarkii. In 2008, the pond was successfully restocked with $A$. astacus after it had been drained from winter 2006 until summer 2007 and following subsequent calcium hydroxide treatment (Stucki, 2018).

A pond populated by $P$. leniusculus was filled with excavated material to restore a disused gravel pit (Kiesgrube Rohr). This measure was successful in eradicating the isolated crayfish population (Stucki, 2018). 
TABLE 1 | Measures to control populations of NICS which were applied in Swiss waters.

\begin{tabular}{|c|c|c|c|c|c|c|c|}
\hline Site name & Water type & Species & Aim & Method & Duration & Change of CPUE & Success \\
\hline Aubach & Lotic & P. leniusculus & Suppression & Trapping & Continous since 2009 & Increase by $100 \%$ & $\mathrm{No}^{\star \star}$ \\
\hline Birsig & Lotic & P. leniusculus & Suppression & Trapping & Continous since 1997 & - & Unclear* \\
\hline Brook Near Origlio & Lotic & P. clarkii & Suppression & Trapping & Since 2013 & Increase by $30 \%$ & $\mathrm{No}^{* \star}$ \\
\hline Brook Near Origlio & Lotic & P. clarkii & Suppression & Electricity & Since 2013 & Increase by $30 \%$ & $\mathrm{No}^{* \star}$ \\
\hline Brook Near Origlio & Lotic & P. clarkii & Suppression & Hand catch & Since 2013 & Increase by $30 \%$ & $\mathrm{No}^{\star *}$ \\
\hline Dättwiler Weiher & Lentic & P. leniusculus & Suppression & Trapping & Continous since 1997 & Decrease by $75 \%$ & Yes $^{\star \star}$ \\
\hline Dättwiler Weiher & Lentic & P. leniusculus & Containment & Overflow pipe & Since 2002 & - & Yes $^{\star \star}$ \\
\hline Dättwiler Weiher & Lentic & P. leniusculus & Suppression & Predatory fish & Campagin in the 90s & Decrease by $75 \%$ & Yes $^{\star \star}$ \\
\hline Depotsee Bern & Lentic & O. limosus & Suppression & Hand catch & 1999-2004 & - & Unclear $^{\star}$ \\
\hline Egelsee & Lentic & F. limosus & Containment & Overflow pipe & Since 2013 & - & Unclear $^{\star}$ \\
\hline Eisweiher & Lentic & P. leniusculus & Suppression & Trapping & Since 2013 & Increase by $20 \%$ & $\mathrm{No}^{\star \star}$ \\
\hline Etzgerbach & Lotic & P. leniusculus & Containment & Crayfish barrier & Since 2015 & $100 \%$ & Yes $^{\star \star}$ \\
\hline Fischzucht Heuwies & Lentic & P. leniusculus & Eradication & Drainage & 2012-2014 and 2019 & - & Unclear $^{*}$ \\
\hline Greifensee & Lentic & O. limosus & Suppression & Predatory fish & Campaign 2019 & - & Unclear* \\
\hline Katzensee & Lentic & P. clarkii & Suppression & Trapping & Since 2015 & - & Unclear $^{\star}$ \\
\hline Katzensee & Lentic & P. clarkii & Suppression & Predatory fish & 2019 & - & Unclear ${ }^{\star}$ \\
\hline Kiesgrube Rohr & Lentic & P. clarkii & Eradication & Filled-in & Campagin in the 90s & - & Yes $^{\star \star}$ \\
\hline Kunzareal Rheinfelden & Lentic & P. clarkii & Eradication & Drainage & $2006 / 2007$ & - & Yes $^{\star *}$ \\
\hline L'étang de Vidy & Lentic & P. clarkii & Eradication & Drainage & 2008 et 2010 & - & $Y_{e s}^{* *}$ \\
\hline Lützel & Lotic & P. leniusculus & Containment & Crayfish barrier & Since 2016 & - & Unclear $^{*}$ \\
\hline Mellinger Lanklagerweiher & Lentic & P. clarkii & Suppression & Trapping & Since 1997 & - & $\mathrm{No}^{\star *}$ \\
\hline Mellinger Tanklagerweiher & Lentic & P. clarkii & Suppression & Predatory fish & Since 1997 & - & $\mathrm{No}^{\star *}$ \\
\hline Mellinger Tanklagerweiher & Lentic & P. clarkii & Eradication & Biocide & Campagin in 2007 & - & $\mathrm{No}^{* *}$ \\
\hline Mellinger Tanklagerweiher & Lentic & P. clarkii & Containment & Catch basket & Since 2000-2016 & - & Unclear* \\
\hline Mellinger Tanklagerweiher & Lentic & P. clarkii & Containment & infiltration system & since 2016 & - & Unclear $^{*}$ \\
\hline Pisciculture de Saint-Victor & Lentic & P. leniusculus & Suppression & Predatory fish & Campaign in 2020 & - & Unclear* \\
\hline Pisciculture de Saint-Victor & Lentic & P. leniusculus & Suppression & Trapping & Since 2020 & - & Unclear* $^{*}$ \\
\hline Pond Near Passeiry & Lentic & P. leniusculus & Suppression & Predatory fish & Campaign in 2020 & Decrease by $100 \%$ & Yes $^{\star \star}$ \\
\hline Pond Near Passeiry & Lentic & P. leniusculus & Suppression & Trapping & Since 2020 & Decrease by $100 \%$ & $Y_{e s}^{\star \star}$ \\
\hline Pfaffnern & Lotic & P. leniusculus & Containment & Crayfish barrier & Since 2017 & - & $Y_{e s}^{\star \star}$ \\
\hline Riehenteich & Lentic & P. leniusculus & Suppression & Trapping & Since 2009 & Increase by $70 \%$ & $\mathrm{No}^{\star \star}$ \\
\hline Roulave & Lotic & P. leniusculus & Containment & Crayfish barrier & Planned for 2021 & - & Unclear $^{*}$ \\
\hline Rumensee & Lentic & P. clarkii & Suppression & Trapping & 2007 and 2018 & - & Unclear $^{*}$ \\
\hline Schübelweiher & Lentic & P. clarkii & Suppression & Trapping & Start 2002 & Decrease by $75 \%$ & $Y_{e s}^{\star \star}$ \\
\hline Schübelweiher & Lentic & P. clarkii & Suppression & Predatory fish & Start 2002 & Decrease by $75 \%$ & $Y_{e s}^{\star \star}$ \\
\hline Stadtbach, Baden & Lotic & P. leniusculus & Suppression & Hand catch & Since 1997 & - & $\mathrm{No}^{\star \star}$ \\
\hline Stadtbach, Baden & Lotic & P. leniusculus & Suppression & Electricity & Campagne in the 90s & - & $\mathrm{No}^{* \star}$ \\
\hline Stadtbach, Baden & Lotic & P. leniusculus & Eradication & Drainage & 2004 and 2005 & - & $Y_{e s}^{\star \star}$ \\
\hline Steinbruch Mellikon & Lentic & P. clarkii & Eradication & Drainage & Campaign 2013 & - & $Y_{e s}^{\star \star}$ \\
\hline Wenkenweiher & Lentic & A. leptodactylus & Suppression & Trapping & Since 2009 & Increase by $30 \%$ & $\mathrm{No}^{* \star}$ \\
\hline
\end{tabular}

Le, Lentic water; L, lotic water; Data rating: * $=$ insufficient; ${ }^{* \star}=$ valid.

In Fischzucht Heuwies, an attempt to completely remove a population of $P$. leniusculus by draining the fish pond from December 2012 to April 2014 was almost successful. No crayfish was found during monitoring from 2015 to 2018. In 2019, the pond was drained again to carry out construction works to reconnect the pond to the brook. In the drained pond, 


\section{Different aims and success of applied measures}

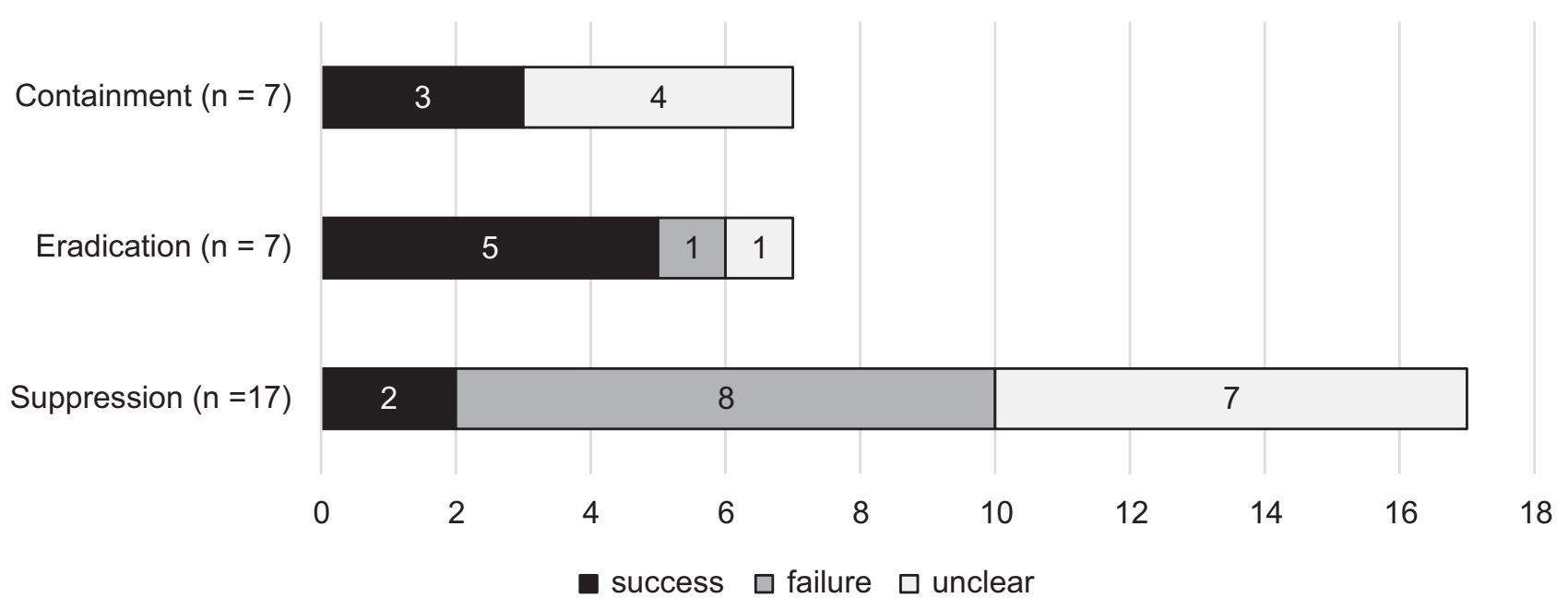

FIGURE 1 | Success of the different measures compiled by aim (containment, eradication, supression). Multi-method approaches were only counted once.

12 P. leniusculus were found in multiple hand catches. During construction work, the drained pond was mechanically treated and the majority of the soil at the bottom of the pond was removed $\left(\sim 10,000 \mathrm{~m}^{-3}\right)$. Since reconstruction, no invasive crayfish have been detected with traps or using eDNA. The success of the eradication measure in Fischzucht Heuwies is still open as it was conducted only one year before publication of this article.

\section{Biocides}

Liquid manure was used in an attempt to eradicate a population of $P$. clarkii living in an artificial outflow culvert of a pond (Mellinger Tanklagerweiher). The culvert was blocked at one end and filled with liquid manure from cows and hens and left for $48 \mathrm{~h}$ before being removed. Complete eradication of crayfish in the treated area was not possible using this method (Stucki, 2018).

In the 1990s, the fishing authorities planned to treat two ponds (Schübelweiher, Rumensee) inhabited by invasive P. clarkii with fenthion, an insecticide used to kill mosquitos, fleas and ticks as well as any unwanted fish and crayfish in fish breading stations. However, the project was stopped due to protests from nature conservation organisations including the WWF and local activists about the predicted negative impacts which fenthion would have had on other aquatic life. An alternative action plan was carried out avoiding the use of harmful chemicals; the combined use of predatory fish and trapping were sufficient to regulate the invasive crayfish population and reduce their negative impacts on ecosystem (Borner et al., 1997, 1998; Frutiger and Müller, 2002).

\section{Suppression of NICS}

To suppress NICS mechanical removal by traps, hand-catch, electricity and introduction of predatory fish were applied. In
2 of 12 lentic waters $(\sim 17 \%)$ trapping of $P$. leniusculus in combination with the introduction of predatory fish led to a $75 \%$ reduction in CPUE. In six of the lentic waters, data was classified as "unclear" and in four cases there was no success despite valid data. In lotic waters, three of the control methods applied were so far unsuccessful and one success was unclear.

\section{Mechanical Removal}

Tapping of crayfish was carried out by cantonal fishery authorities (pond near Passeiry and Pisciculture de Saint-Victor), community service workers (Aubach, Birsig, Eisweiher, Riehenteich, and Wenkenweiher), water tenants (Dättwiler Weiher, Katzensee, Mellinger Tanklagerweiher, Rumensee, and Schübelweiher) and by a private environmental company (brook near Origlio). A corresponding permit from the responsible department for fisheries is needed to be allowed to catch invasive crayfish in Switzerland. Water tenants were obliged to remove crayfish of all age groups and of both sexes and were forbidden to put any back after they had been caught. Crayfish from Mellinger Tanklagerweiher, Schübelweiher, und Katzensee were sold to restaurants to be eaten.

At sites where trapping was combined with introduction of predatory fish a reduction in CPUE of $75 \%$ was observed in Dättwiler Weiher, Schübelweiher and 100\% in Pisciculture de Saint-Victor. In Mellinger Tanklagerweiher, no change in CPUE was observed over 19 years despite the introduction of pike. In the pond near Passeiry, the CPUE decreased from 10.9 to 0 from mid-July to beginning of September. At this site, artificial refuge traps (ARTs) were used in addition to "pirate" traps (BockÅs Ltd., Finland). However, only $0.4 \%$ of the 2,480 individuals 
caught at Passeiry were trapped in ARTs; these were mainly small indiviudals ( $<8 \mathrm{~cm}$ total length, sex ratio 5:4).

\section{Electricity}

Three methods of electricity exposure were tested to try to eradicate $P$. leniusculus in a $300 \mathrm{~m}$ long stretch of a culvertisolated stream (Stadtbach, Baden); direct current (electric fishing gear, $500 \mathrm{~V}, 5 \mathrm{~A}, 30 \mathrm{~s}$ exposure), impulse current (electric fishing gear, $1,000 \mathrm{~V}, 1 \mathrm{~A}, 100 \mathrm{~Hz}, 5 \mathrm{~s}$ exposure) and alternating current (fish killing gear, $40 \mathrm{~V}, 0.35 \mathrm{~A}, 50 \mathrm{~Hz}, 60 \mathrm{~s}$ exposure). Crayfish exhibited strong behavioural reactions to the impulse current when alternating and direct current were applied but there were no mortalities of crayfish (Stucki, 2018).

However, electrofishing devices were successful in catching P. clarkii in a small brook near Origlio; on average four electrofishing-campaigns were implemented each year. At this site, electrofishing, trapping and hand catch have been used in combination for 5 years. In this brook more crayfish could be caught using electrofishing compared to trapping and hand-catch during night-time inspections. Nevertheless, there has not yet been significant decrease in the number of crayfish caught so far.

\section{Introduction of Predatory Fish}

Pike, Esox lucius (Linnaeus, 1758), perch, Perca fluviatilis (Linnaeus, 1758), zander, Sander lucioperca (Linnaeus, 1758), and $A$. anguilla are all predatory species which were introduced individually or combination into seven lentic waters to reduce the occurrence of three invasive crayfish; P. lenisculus (Dättwiler Weiher, Pisciculture de Saint-Victor, and pond near Passeiry), P. clarkii (Mellinger Tanklagerweiher, Katzensee, Schübelweiher), and F. limosus (Greifensee).

The introduction of eel into Pisciculture de Saint-Victor and the pond near Passeiry was conducted in summer 2019 and results are from autumn of the same year. In two of the lentic waters, the release of predatory fish in combination with the use of trapping, led to a reduction in CPUE of 75\%; after three (Dättwilerweiher) and six years (Schübelweiher). In four cases, success cannot be assessed due to the insufficient data gathered so far (Greifensee, Katzensee, Pisciculture de Saint-Victor, and pond near Passeiry). A reduced tendency of $P$. clarkii to spread over land was reported by the local fishery department after implementation of control measures in Schübelweiher, Katzensee, and Mellinger Tanklagerweiher.

\section{Containment of NICS}

To prevent further spread of NICS several barriers were constructed in Switzerland. Three out of eight barriers have so far proven their success. For the other five, an assessment of success is not yet possible and have so far been classified as "unclear".

\section{Crayfish Barriers in Lentic Waters}

It was attempted to stop the spread of F. limosus from a two hectare lake (Egelsee) into an adjoining river by covering the outlet drain with a metal mesh cage which was filled with stones. This construction must be regularly cleaned because the banks will be flooded if it becomes clogged. It was later discovered that the protected river had been populated by F. limosus from another river section and therefore success of this construction was deemed "unclear".

In a pond (Dättwiler Weiher), an overflow pipe was installed several meters away from the bank in order to stop the migration of $P$. leniusculus from the pond into the adjoining brook. So far there has been no evidence of invasive crayfish present in the outflow brook.

A catch basket was installed at the end of the culvert in order to stop P. clarkii spreading from the two-hectare lake Tanklagerweiher Mellingen into the outflowing brook. The catch basket had to be emptied and cleaned when clogged; the frequency of cleaning was dependant on season. An infiltration system with gravel was installed directly at the outflow of the lake in order to reduce maintenance efforts at this site. The success could not be confirmed so far, as some of the invasive crayfish have already established downstream of the construction. These individuals must first be eliminated before the success of the catch basket as a control method can be assessed.

\section{Crayfish Barriers in Lotic Waters}

In the Etzgerbach, a crayfish barrier was built to prevent $P$. leniusculus from migrating into the headwaters where native A. torrentium are found. The barrier consisted of a $30 \mathrm{~cm}$ free fall with a steel overhanging lip. A function control with native A. astacus could confirm that the barrier functioned in preventing crayfish movement upstream while also allowing migration of trout (Salmo trutta fario Linnaeus 1758) with a body length ranging from 11.5 to $49 \mathrm{~cm}$.

Another barrier with the same design as in Etzgerbach was built in the river Lützel in order to protect the habitat of A. pallipes from $P$. leniusculus invasion. There has been no detection of $P$. leniusculus in traps upstream of the barrier, even 4 years after its construction.

A $40 \mathrm{~cm}$ high crayfish barrier made out of stainless steel with a fish passable mid-section was built with connection to the river bed in the Pfaffnern. The stainless steel created smooth surfaces that in combination with high water velocities, $\geq 0.65 \mathrm{~m} / \mathrm{s}$, aimed to stop P. leniusculus from spreading further upstream (Frings et al., 2013). PIT-tagged $A$. astacus were released downstream of the barrier to verify if crayfish could overcome the barrier. No released $A$. astacus was detected upstream of the barrier during the 8 month study.

\section{DISCUSSION}

\section{Eradication of NICS} Temporary Drainage or Destruction of a Habitat

Complete destruction of an isolated waterbody has led to a successful eradication of the invasive crayfish population in Kiesgrube Rohr and is the most promising method for future eradication attempts. Although drainage of waterbodies has been successful (Steinbruch Mellikon and l'étange de Vidy), if the water is only drained for a few months, there is always the risk that some crayfish will survive in burrows or humid places and can rebuild 
a stock (Fischzucht Heuwies). Treatment with calcium hydroxide can in this case increase success possibility (l'étange de Vidy and Kunzareal Rheinfelden).

It is difficult to definitively state that there are no crayfish inhabiting a particular waterbody after an eradication effort. Eradication is only considered successful after 2-5 years of monitoring without a crayfish detection (Peay et al., 2006). Trapping, night inspections and eDNA testing should be used in combination to effectively evaluate the presence of crayfish.

\section{Biocides}

Although the use of biocides is considered the cheapest and most efficient method to eradicate unwanted crayfish populations (Manfrin et al., 2019), they have never been used in Switzerland, with the exception of liquid manure. Examples from Scotland (Peay et al., 2019) and Sweden (Ljunggren and Sundin, 2010) demonstrate that the use of biocides can be successful in eradicating NICS in isolated waters systems and that non-target invertebrates start recolonisation within a month after treatment.

\section{Difficulties in Eradicating NICS}

The extinction vortex and minimum viable population density is species-specific and depends on predation, reproduction strategy and environmental factors-food source, habitat size, and disease (Fagan and Holmes, 2006). In theory, only a single male and female are needed to successfully rebuild a population. One study showed that recolonisation could theoretically begin with as little as eleven individuals in an isolated water of $1 \mathrm{~km}^{2}$, this figure was calculated from walking distances of male P. leniusculus during breeding season (Peay, 2001). With such a small original population there can be problems with inbreeding which can result in low genetic diversity, meaning an entire population could more easily be wiped out by disease or by a natural disaster. Establishment of all populations of $F$. limosus in Europe can be traced back to the introduction of only 90 individuals (Filipová et al., 2011), underlining the fact that even if only a few individuals remain after a control measure this can be sufficient enough to build up the population again (Henttonen and Huner, 1997). For marbled crayfish (Procambarus virginalis Lyko, 2017), a species which reproduce by parthenogenesis, it is theoretical even possible to rebuild a population with only one individual (Ercoli, 2019). In this case, the probability of extinction is again much higher due to environmental factors, predation and failure to breed.

\section{Suppression of NICS Mechanical Removal}

At sites where mainly adult crayfish were caught in traps, no reduction in population size was observed (Aubach, Wenkenweiher Riehen, Eisweiher, Riehenteich). According to our data and in agreement with previous studies, the use of various techniques to reduce the population size clearly achieves better results than a single control approach (Manfrin et al., 2019). Species with high fecundity and early maturity react undesirably to harvest control measures because the niche of the removed adult crayfish is quickly taken over by younger individuals (Zipkin et al., 2009). This fact can explain the increase in CPUE at Aubach, Eiweiher, Riehenteich, Wenkenweiher, and in the brook near Origlio. Evaluating whether NICS eradication measures have been successful can take several years (Peay, 2001). Therefore, in order to prevent the population from rebuilding, the use of traps and other control methods must continue even when no more animals are caught.

In the Passeiry, the CPUE decreased to zero after one year of intense trapping with "pirate" traps and ARTs as well as after the introduction of eels. The treatment was only conducted for one year so success cannot yet be guaranteed. Trapping was stopped when no more crayfish were caught with traps. Traps have been shown to only catch a minority of the population (Chadwick et al., 2020), therefore, it can be assumed that there are still some crayfish occurring in the Passeiry and so trapping should be continued to avoid population numbers bouncing back. There was limited success to reduce invasive crayfish populations using ARTs in the Passeiry. In a typical upland river in the south-west of England more juvenile and female P. leniusculus were caught in ARTs than in conventional traps indicating the advantage of applying this method (Green et al., 2018). The poor catch rate in ARTs in the Passeiry could be because there are many naturally existing refuges already present in the banks, which makes the traps a less attractive refuge for the crayfish. Another reason for the lack of success of ARTs in Switzerland could be the fact that the number of crayfish was quickly lowered by the eels introduced at the same time as the traps.

For Birsig, Katzensee, Greifensee, and Rumensee no data is available regarding effort and catch numbers: therefore, it is not possible to evaluate success in suppressing these populations of NICS. For this reason it is important to use CPUE values or the capture-mark-recapture (CMR) technique to estimate the population size and assess the success of the method (Zimmerman and Palo, 2011).

Invasive crayfish fishing and sale has never led to eradication of a NICS population in Switzerland. The creation of a culinary market for invasive crayfish promotes illegal stocking and means that the population of invaders is maintained instead of eradicated (Nuñez et al., 2012). This issue is also highlighted in the IAA Gotland Resolution, which was formulated at the "IAA Gotland 2019 Crayfish conference" (Edsman, 2019).

\section{Electricity}

In Switzerland, the use of electricity in an isolated section of the Stadtbach, Baden was not effective in eradicating P. leniusculus. However, the use of repeated high intensity (69 W, direct current $1,600 \mathrm{~V}, 57.8 \mathrm{~A}$, at $7 \mathrm{~Hz}$ ) shocks resulted in high mortality (86$97 \%$ ) of $P$. leniusculus inhabiting a stony headwater stream in England (Peay et al., 2014). In the treatment in England, they used $1.6 \mathrm{~V}$ and amps eleven times higher than in Stadtbach, Baden. This could be the reason for the failure to eradicate the invasive population at this site.

In a small stream (brook near Origlio), even the use of electrofishing combined with night inspections and the use of traps, could not reduce the catch number of $P$. clarkii over 5 years. One reason for this could be due to the specific life-history traits 
of $P$. clarkii including its high fecundity and early maturity which allows fast population recovery (Chucholl, 2011).

\section{Introduction of Predatory Fish}

In Switzerland, introduction of predatory fish in combination with the use of traps has been successful in reducing recorded overland movements of $P$. clarkii. However, it is assumed that the population size will grow again if trapping is stopped and the number of predatory fish decrease (Paragamian, 2010). The use of native predatory fish is regarded as a good way to reduce the number of juvenile crayfish and complements trapping which removes reproducing adults (Elvira et al., 1996; Aquiloni et al., 2010; Musseau et al., 2015).

Non-native predators can also reduce crayfish densities (Miyake and Miyashita, 2011). Thus, the removal of invasive predatory fish, namely, pike, perch or catfish, from conservation ponds, can lead to an increase in the population size of invasive crayfish; consequently, causing negative effects on other animal and plant species. The release of native predatory fish in previously uninhabited waters can also have a negative impact on the other species present, including amphibians (Braña et al., 1996; Hecnar and M'Closkey, 1997). Since invasive crayfish also have a negative influence on native plants and animals, the pros and cons of each control method must be considered to determine which will be most beneficial for each site.

Catching of predatory fish in waterways with NICS should be prohibited or regulated. If recreational fishing is allowed in certain ponds, new groups of predatory fish should be regularly introduced to the water system to ensure that their numbers are kept high; therefore, maximising the effect of predatory fish on crayfish.

\section{Containment of NICS}

Preventing the further spread of NICS through artificial or natural barriers is an important tool for invasive species management. The use of artificial barriers or modification to existing structures prevents the further spread of invasive crayfish and is a more cost-effective method compared to carrying out never-ending stock control when crayfish have invaded new sections of a lotic water. In Switzerland, the erection of barriers is part of the national strategy to prevent NICS from interfering with further waters (Stucki and Zaugg, 2006).

The crayfish barriers in the Etzgerbach, Lützel, and Pfaffnern which are mentioned in this paper were so far able to prevent upstream movement of crayfish. Barriers are the only known way to stop the natural spread of NICS within a water system. On the other hand, crayfish barriers can impede the migration of poor swimming fish; therefore, each new case a balance of interests has to be made as to whether fish migration or the prevention of the spread of NICS is more important (Krieg and Zenker, 2020). Most crayfish barriers will be constructed to protect side waters which are mainly inhabited by trout. Functional controls carried out at the barrier in the Etzgerbach highlighted that marked trout were able to overcome the crayfish barrier here; indicating that trout are not negatively affected by artificial crayfish barriers.
Despite the lack of function control in Mellinger Tanklagerweiher, the use of an infiltration system is a promising method to prevent the spread of NICS from a pond into an adjoining brook as it is not physically possible for crayfish to dig through this infiltration system.

\section{Combination of Different Methods}

According to the results of this study, success in suppression of an NICS population can be better achieved by using a combination of several control methods (electricity, ARTs, handcatch, traps, and predatory fish) rather than applying just one method on its own. The reduction in size of populations of NICS was achieved exclusively in lentic waters, when combining the use of traps with the stocking of predatory fish. Predatory fish have a larger impact on preventing population growth rate than traps because they target the offspring which are responsible for future population growth. Traps on the other hand have a larger impact on breeding adults and they often miss juveniles which are small and can escape through gaps in the traps (Hein et al., 2006). The selectiveness of each method means that they should be used in combination to be most effective. If the majority of adult crayfish are caught in traps, there can be an increase in reproduction in the population whereby females produce more eggs at a younger age and there is a higher rate of survival of juveniles because of lower intraspecific predation and increased food availability (Momot, 1998).

\section{Data Collection}

In this study, data showed that no conclusions could be drawn about the success of the control measures in $\sim 43 \%$ of the sites $(n=12)$. However, in $57 \%$ of treated waters $(n=16)$, the data could be used to assess the success of the method and whether its continuation is appropriate.

The meticulous collection of catch data, in particular the determination of the CPUE, is mandatory in order to assess the growth of a population over time, thus the success of a control measure (Schwarz and Seber, 1999). By catching and measuring all age groups, it is also possible to make an assessment of the number of reproducing individuals and highlight any visible population growth trends (Rabeni et al., 1997; Paillisson et al., 2011). Another technique to evaluate population size is CMR which is a promising option in smaller ponds (Coignet et al., 2012).

\section{Conclusion}

It is more effective to completely eradicate an invasive species with drastic measures as soon as it is found inhabiting a water rather than continuously reducing population densitiy by suppression or isolating a population by containment (Simberloff 2014). Populations of NICS should be removed as soon as possible to avoid further damage and destruction of the habitat for native species. If the use of biocides is not possible, it is recommended to drain or destroy water bodies whenever possible to eradicate populations of NICS. Suppression and containment methods can be used to minimise the negative effects which NICS have on a habitat. 
A combination of trapping and introduction of predatory fish has proven successful as a suppression multi-method approach. Crayfish barriers are the only way to contain an established NICS population to ensure that they are isolated from invading further upstream. Global warming may pose further problems as invasive species are advantaged by the increasing water temperatures, meaning they will be able to spread even faster and colonise previously inappropriate habitats (Rahel and Olden, 2008).

It is important that measures to control invasive species are carried out and agreed nationwide and across countries to prevent spread from places where no measures are taken. This is always a difficult issue to overcome when trying to control an invasive species of animal or plant, as land or municipal boundaries set by humans do not apply to them (Fernandes et al., 2019; Beaury et al., 2020). The development of a common strategy based on the experience gained to date can significantly increase success of invasive species eradication as well as saving money, the environment and the species inhabiting it.

\section{REFERENCES}

Aquiloni, L., Brusconi, S., Cecchinelli, E., Tricarico, E., Mazza, G., Paglianti, A., et al. (2010). Biological control of invasive populations of crayfish: the European eel (Anguilla anguilla) as a predator of Procambarus clarkii. Biol. Invasions 12, 3817-3824. doi: 10.1007/s10530-010-9774-z

Ballantyne, L., Baum, D., Bean, C. W., Long, and, J., and Whitaker, S. (2019). "Successful eradication of signal crayfish (Pacifastacus leniusculus) using a nonspecific biocide in a small isolated water body in Scotland," in 2019 Isl. Invasives Scaling up to Meet Challenge. Occas. Pap. SSC no. 62, eds C. R. Veitch, M. N. Clout, A. R. Martin, J. C. Russell C. J. West (Dundee: IUCN), 443-446.

Beaury, E. M., Fusco, E. J., Jackson, M. R., Laginhas, B. B., Lyn, T., Jenica, M., et al. (2020). Incorporating climate change into invasive species management: insights from managers. Biol. Invasions 22, 233-252. doi: 10.1007/s10530-019-02087-6

Bills, T. D., and Marking, L. L. (1988). Control of nuisance populations of crayfish with traps and toxicants. Progres Fish Cultu. 50, 103-106. doi: 10.1577/15488640(1988)050<0103:CONPOC>2.3.CO;2

Borner, S., Büsser, T., Eggen, R., Fent, K., and Frutiger, A. (1997). Der Rote Sumpfkrebs - Situationsanalyse und Vorschläge für Bekämpfungsmassnahmen. Eawag Swiss Fed. Inst. Aquat. Sci. Technol. Dübendorf. 27.

Borner, S., Büsser, T., Eggen, R., Frutiger, A., Müller, R., Müller, S., et al. (1998). Der Rote Sumpfkrebs im Schübelweiher - Auswertung der Massnahmen 1997. Eawag Swiss Fed. Inst. Aquat. Sci. Technol. Dübendorf. 23.

Braña, F., Frechilla, L., and Orizaola, G. (1996). Effect of introduced fish on amphibian assemblages in mountain lakes of northern Spain. Herpetol. J. 6, 145-148.

Burič, M., Hulák, M., Kouba, A., Petrusek, A., and Kozák, P. (2011). A successful crayfish invader is capable of facultative parthenogenesis: a novel reproductive mode in decapod crustaceans. PLOS ONE 6:e0020281. doi: 10.1371/journal.pone.0020281

Cecchinelli, E., Aquiloni, L., Maltagliati, G., Orioli, G., Tricarico, E., and Gherardi, F. (2012). Use of natural pyrethrum to control the red swamp crayfish Procambarus clarkii in a rural district of Italy. Pest Manag. Sci. 68, 839-844. doi: $10.1002 /$ ps.2335

Chadwick, D. D. A., Pritchard, E. G., Bradley, P., Sayer, C. D., Chadwick, M. A., Eagle, L. J. B., et al. (2020). A novel 'triple drawdown' method highlights deficiencies in invasive alien crayfish survey and control techniques. J. Appl. Ecol. 29. doi: 10.1111/1365-2664.13758

\section{DATA AVAILABILITY STATEMENT}

The original contributions presented in the study are included in the article/supplementary materials, further inquiries can be directed to the corresponding author/s.

\section{AUTHOR CONTRIBUTIONS}

$\mathrm{RK}, \mathrm{AK}$, and $\mathrm{AZ}$ conceived the ideas and designed the methodology. RK collected and analysed the data. AK and AZ led to the writing of the manuscript and contributed critically to the drafts and all authors gave final approval for publication.

\section{ACKNOWLEDGMENTS}

The Authors would like to thank the following people for providing the data for this paper: Cédric Henry, Daniel Zopfi, Daniel Bernet, Danilo Foresti, Gabriel Sutter, Gottlieb Dandliker, Hans-Peter Jermann, Lukas Bammatter, Michael Kugler, Mirko Zanini, Rainer Kühnis, and Thomas Stucki.

Chucholl, C. (2011). Population ecology of an alien "warm water" crayfish (Procambarus clarkii) in a new cold habitat. Knowl. Manag. Aquat. Ecosyst. 401, 1-21. doi: 10.1051/kmae/2011053

Coignet, A., Pinet, F., and Souty-Grosset, C. (2012). Estimating population size of the red swamp crayfish (Procambarus clarkii) in fish-ponds (Brenne, Central France). Knowl. Manag. Aquat. Ecosyst. $406: 11$ doi: 10.1051/kmae/20 12019

Cowart, D. A., Breedveld, K. G. H., Ellis, M. J., Hull, J. M., and Larson, E. R. (2018). Environmental DNA (eDNA) applications for the conservation of imperiled crayfish (Decapoda: Astacidea) through monitoring of invasive species barriers and relocated populations. J. Crustac. Biol. 38, 257-266. doi: $10.1093 /$ jcbiol/ruy007

Edsman, L. (2019). Gotland Resolution. Crayfish News 41, 10-13.

Elvira, B., Gnicola, G., and Almodovar, A. (1996). Pike and red swamp crayfish: a new case on predator-prey relationship between aliens in central Spain. J. Fish Biol. 48, 437-446. doi: 10.1006/ffbi.1996.0043

Ercoli, F. (2019). First record of an established marbled crayfish Procambarus virginalis (Lyko, 2017) population in Estonia. BioInvasions Rec. 8, 675-683. doi: 10.3391/bir.2019.8.3.25

Fagan, W. F., and Holmes, E. E. (2006). Quantifying the extinction vortex. Ecol. Lett. 9, 51-60. doi: 10.1111/j.1461-0248.2005.00845.x

Fernandes, R. F., Honrado, J. P., Guisan, A., Roxo, A., Alves, P., Martins, J., et al. (2019). Species distribution models support the need of international cooperation towards successful management of plant invasions. J. Nat. Conserv. 49, 85-94. doi: 10.1016/j.jnc.2019.04.001

Filipová, L., Lieb, D. A., Grandjean, F., and Petrusek, A. (2011). Haplotype variation in the spiny-cheek crayfish Orconectes limosus: colonization of Europe and genetic diversity of native stocks. J. North Am. Benthol. Soc. 30, 871-881. doi: 10.1899/10-130.1

Freeman, M. A., Turnbull, J. F., Yeomans, W. E., Bean, C. W., Lumpur, K., Foundation, C. R., et al. (2010). Prospects for management strategies of invasive crayfish populations with an emphasis on biological control. Aquat. Conserv. Mar. Freshw. Ecosyst. 20, 211-223. doi: 10.1002/aqc.1065

Frings, R. M., Vaeßen, S. C. K., Gro,ß, H., Roger, S., Schüttrumpf, H., and Hollert, H. (2013). A fish-passable barrier to stop the invasion of non-indigenous crayfish. Biol. Conserv. 159, 521-529. doi: 10.1016/j.biocon.2012.12.014

Frutiger, A., and Müller, R. (2002). Der Rote Sumpfkrebs im Schübelweiher: Auswertung der Massnahmen 1998 - 2001 und Erkenntnisse. Eawag Swiss Fed. Inst. Aquat. Sci. Technol. Dübendorf. 26. 
Gherardi, F. (2006). Crayfish invading Europe: the case study of Procambarus clarkii. Mar. Freshw. Behav. Physiol. 39, 175-191. doi: $10.1080 / 10236240600869702$

Girardet, M., Cherix, D., Hofmann, F., and Rubin, J. (2012). Eradication d'une population d'écrevisses de Louisiane, Procambarus clarkii, à l'étang de Vidy et situation des populations d'écrevisses à Lausanne, Suisse. Bull. Soc. Vaud. Sc. Nat. 93:11. Available online at: https://serval.unil.ch/en/notice/serval:BIB_ 67962B5СA8CB

Green, N., Bentley, M., Stebbing, P., Andreou, D., and Britton, R. (2018). Trapping for invasive crayfish: comparisons of efficacy and selectivity of baited traps versus novel artificial refuge traps. Knowl. Manag. Aquat. Ecosyst. 419:9. doi: 10.1051/kmae/2018007

Hecnar, S. J., and M'Closkey, R. T. (1997). The effects of predatory fish on amphibian species richness and distribution. Biol. Conserv. 79, 123-131. doi: 10.1016/S0006-3207(96)00113-9

Hefti, D., and Stucki, P. (2006). Crayfish management for Swiss waters. Bull. Français la Pêche la Piscic. 937-949. doi: 10.1051/kmae:2006033

Hein, C. L., Roth, B. M., Ives, A. R., and vander Zanden, M. J. (2006). Fish predation and trapping for rusty crayfish (Orconectes rusticus) control: a whole-lake experiment. Can. J. Fish. Aquat. Sci. 63, 383-393. doi: 10.1139/f05-229

Hein, C. L., Vander Zanden, M. J., and Magnuson, J. J. (2007). Intensive trapping and increased fish predation cause massive population decline of an invasive crayfish. Freshw. Biol. 52, 1134-1146. doi: 10.1111/j.1365-2427.2007.01741.x

Henttonen, P., and Huner, J. V. (1997). "The introduction of alien species of crayfish in Europe: A historical introduction," in Crayfish in Europe as Alien Species: How to Make the Best of the Bad Situation? eds F. Gherardi, and D. M. Holdich (Rotterdam: A. A. Balkema), 13-22. doi: 10.1201/9781315140469-2

Holdich, D. M., Reynolds, J. D., Souty-Grosset, C., and Sibley, P. J. (2009), A review of the ever increasing threat to European crayfish from nonindigenous crayfish species. Knowl. Manag. Aquat. Ecosyst. 11, 394-395. doi: 10.1051/kmae/2009025

Kouba, A., Petrusek, A., and Kozák, P. (2014). Continental-wide distribution of crayfish species in Europe: update and maps. Knowl. Manag. Aquat. Ecosyst. 413, 31. doi: $10.1051 / \mathrm{kmae} / 2014007$

Krieg, R., and Zenker, A. (2020). A review of the use of physical barriers to stop the spread of non-indigenous crayfish species. Rev. Fish Biol. Fish 30, 423-435. doi: 10.1007/s11160-020-09606-y

Ljunggren, N., and Sundin, J. (2010). Eliminering av Signalkräfta på Gotland - En Redovisning av Utförda Åtgärder Inom Åtgärdsprogrammet för Bevarande av Flodkräfta Under 2007-2009, Technical Report. Visby, 1-51.

Manfrin, C., Souty-grosset, C., Anast, P. M., Reynolds, J., and Giulianini, P. G. (2019). Detection and control of invasive freshwater crayfish: from traditional to innovative methods. Diversity 11, 1-16. doi: 10.3390/d11010005

Miyake, M., and Miyashita, T. (2011). Identification of alien predators that should not be removed for controlling invasive crayfish threatening endangered odonates. Aquat. Conserv. Mar. Freshw. Ecosyst. 21, 292-298. doi: $10.1002 /$ aqc. 1178

Momot, W. T. (1998). "An example of how exploitation can increase production and yield in a northern crayfish (Orconectes virilis) population," in Proceedings of the North Pacific Symposium on Invertebrate Stock Assessment and Management, eds G. S. Jamieson, and A. Campbell (Ottawa, ON: Natinoal research council of Canada), 225-234.

Musseau, C., Boulenger, C., Crivelli, A. J., Lebel, I., Pascal, M., Boulêtreau, S., et al. (2015). Native European eels as a potential biological control for invasive crayfish. Freshw. Biol. 60, 636-645. doi: 10.1111/fwb.12510

Nuñez, M. A., Kuebbing, S., Dimarco, R. D., and Simberloff, D. (2012). Invasive Species: To eat or not to eat, that is the question. Conserv. Lett. 5, 334-341. doi: 10.1111/j.1755-263X.2012.00250.x

Nyström, P. (2002). "Ecology," in Biology of Freshwater Crayfish, ed D. M. Holdich (Oxford, UK: Blackwell Science), 192-235.

Paillisson, J.-M., Soudieux, A., and Damien, J.-P. (2011). Capture efficiency and size selectivity of sampling gears targeting red-swamp crayfish in several freshwater habitats. Knowl. Manag. Aquat. Ecosyst. 401:12. doi: $10.1051 / \mathrm{kmae} / 2011015$

Paragamian, V. L. (2010). Increase in abundance of signal crayfish may be due to decline in predators. J. Freshw. Ecol. 25, 155-157. doi: 10.1080/02705060.2010.9664369

Peay, S. (2001). Eradication of alien crayfish populations. R\&D Technical Report W1-037/TR1. Environment Agency. Bristol: Almondsbury.

Peay, S., Dunn, A. M., Kunin, W. E., McKimm, R., and Harrod, C. (2014). A method test of the use of electric shock treatment to control invasive signal crayfish in streams. Aquat. Conserv. Mar. Freshw. Ecosyst. 25, 874-880. doi: 10.1002/aqc.2541

Peay, S., Hiley, P. D., Collen, P., and Martin, I. (2006). Biocide treatment of ponds in Scotland to eradicate signal crayfish. Bull. Français la Pêche la Piscic. 380-381, 1363-1379. doi: 10.1051/kmae:2006041

Peay, S., Johnsen, S., Bean, C., Dunn, A., Sandodden, R., and Edsman, L. (2019). Biocide treatment of invasive signal crayfish: successes, failures and lessons learned. Diversity 11:29. doi: 10.3390/d11030029

Piazza, F., Aquiloni, L., Peruzza, L., Manfrin, C., Simi, S., Marson, L., et al. (2015). Managing of Procambarus clarkii by X-ray sterilisation of males: cytological damage to gonads. Micron 77, 32-40. doi: 10.1016/j.micron.2015. 05.016

Rabeni, C. F., Collier, K. J., Parkyn, S. M., and Hicks, B. J. (1997). Evaluating techniques for sampling stream crayfish (Paranephrops planifrons). New Zeal. J. Mar. Freshw. Res. 31, 693-700. doi: 10.1080/00288330.1997. 9516799

Rahel, F. J., and Olden, J. D. (2008). Assessing the effects of climate change on aquatic invasive species. Consercation Biol. 22, 521-533. doi: 10.1111/j.1523-1739.2008.00950.x

Schwarz, C. J., and Seber, G. A. F. (1999). Estimating animal abundance: review III. Stat. Sci. 14, 427-456. doi: 10.1214/ss/1009212521

Stebbing, P., Longshaw, M., and Scott, A. (2014). Review of methods for the management of non-indigenous crayfish, with particular reference to Great Britain. Ethol. Ecol. Evol. 26, 204-231. doi: 10.1080/03949370.2014.9 08326

Stucki, T. (2018). Bekämpfung Amerikanischer Krebsarten im Kanton Aargau. Bot. Gesellschaft Liechtenstein-Sargans-Werdenberg, 35, 33-40.

Stucki, P., and Zaugg, B. (2006). Nationaler Aktionsplan Flusskrebse. Bern: Bundesamt für Umwelt.

Stucki, P., and Zaugg, B. (2011). Aktionsplan Flusskrebse Schweiz. Artenförderung von Edelkrebs, Dohlenkrebs und Steinkrebs. Bern: Bundesamt füür Umwelt. 61.

Westman, K., Savolainen, R., and Julkunen, M. (2002). Replacement of the native crayfish Astacus astacus by the introduced species Pacifastacus leniusculus in a small, enclosed Finnish lake: a 30-year study. Ecography 25, 53-73. doi: 10.1034/j.1600-0587.2002.250107.x

Zimmerman, J. K. M., and Palo, R. T. (2011). Reliability of catch per unit effort (CPUE) for evaluation of reintroduction programs - a comparison of the markrecapture method with standardized trapping. Knowl. Manag. Aquat. Ecosyst. 401:7. doi: $10.1051 / \mathrm{kmae} / 2011016$

Zipkin, E. F., Kraft, C. E., Cooch, E. G., and Sullivan, P. J. (2009). When can efforts to control nuisance and invasive species backfire? Ecol. Appl. 19, 1585-1595. doi: $10.1890 / 08-1467.1$

Conflict of Interest: The authors declare that the research was conducted in the absence of any commercial or financial relationships that could be construed as a potential conflict of interest.

Copyright $(0) 2020$ Krieg, King and Zenker. This is an open-access article distributed under the terms of the Creative Commons Attribution License (CC BY). The use, distribution or reproduction in other forums is permitted, provided the original author(s) and the copyright owner(s) are credited and that the original publication in this journal is cited, in accordance with accepted academic practice. No use, distribution or reproduction is permitted which does not comply with these terms. 